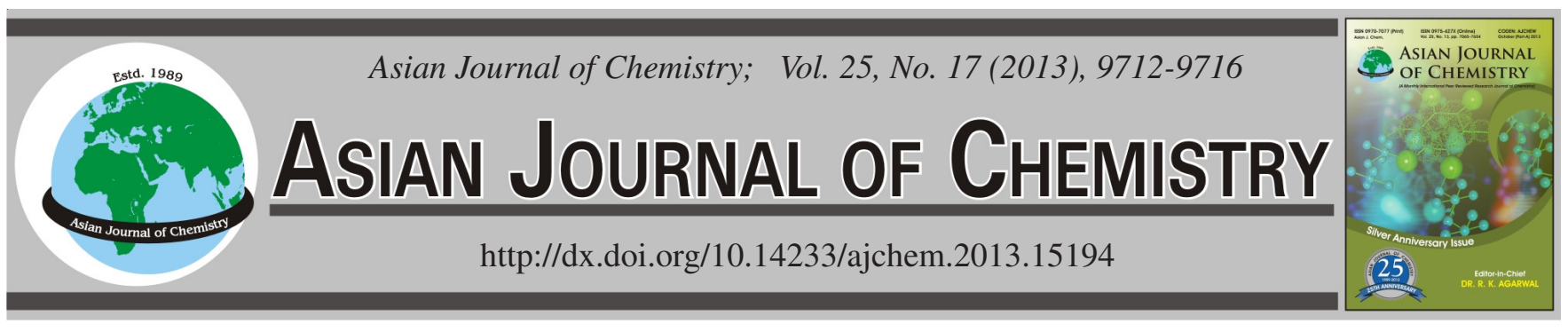

\title{
Assessment of Metals and Metalloids Accumulation in Wastewater Irrigated Soil and Uptake by Pumpkin (Cucurbita maxima) at Sargodha, Pakistan
}

\section{Zafar Iqbal Khan $^{1, *}$, Zahara Bibi ${ }^{1}$, Kafeel Ahmad $^{1}$, Muhammad Ashraf $^{2}$, Nudrat Aisha Akram ${ }^{3}$ and Fahim Arshad ${ }^{4}$}

\author{
${ }^{1}$ Department of Biological Sciences, University of Sargodha, Sargodha, Pakistan \\ ${ }^{2}$ University College of Agriculture, University of Sargodha, Sargodha, Pakistan \\ ${ }^{3}$ Department of Botany, GC University, Faisalabad, Pakistan \\ ${ }^{4}$ Department of Botany, University of Education, Okara Campus, Okara, Pakistan
}

*Corresponding author: E-mail: zikhan11@gmail.com

This research was conducted to evaluate the metal and metalloid concentrations in soil and Cucurbita maxima. A composite of soil and vegetable samples were collected from two sites of district Sargodha, Pakistan receiving domestic sewage water. Soil and vegetable samples were digested and analyzed for metal contents. The levels of six different metals and metalloids in soil viz., $\mathrm{Co}, \mathrm{Ni}, \mathrm{Cu}, \mathrm{As}, \mathrm{Zn}$ and Se were found to be 19.61, 3.29, 11.97, 26.40, 3.84 and $2.36 \mathrm{mg} \mathrm{kg}^{-1}$ at site-I and 19.63, 3.57, 11.76, 26.39, $3.73 \mathrm{and}^{2.29} \mathrm{mg} \mathrm{kg}^{-1}$ at site-II, respectively. The metal contamination levels at both sites were almost similar. The study showed that constant supply of raw water for irrigation resulted in accumulation of metals and metalloids in the vegetable above the maximum permissible limit. The mean concentrations of metals and metalloids in edible portion of Cucurbita maxima in $\mathrm{mg} \mathrm{kg}^{-1}$ at site-I were 0.544 for $\mathrm{Co}, 4.33 \mathrm{for} \mathrm{Ni}, 23.43$ for $\mathrm{Cu}$, 11.72 for $\mathrm{As}, 61.77$ for $\mathrm{Zn}$ and 0.835 for Se and at site-II 0.760 for $\mathrm{Co}, 4.827$ for Ni, 23.49 for $\mathrm{Cu}, 9.097$ for As, 58.65 for $\mathrm{Zn}$ and 0.833 for Se. The transfer factor indicated that $\mathrm{Zn}$ had the strongest capacity of metal accumulation from the soil to the vegetable at both sites.

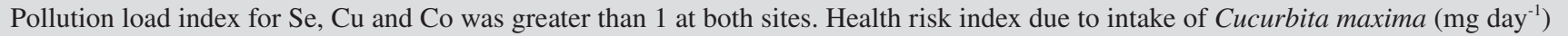
was 0.07 for $\mathrm{Co}, 1.24$ for $\mathrm{Ni}, 3.37$ for $\mathrm{Cu}, 224.63$ for As, 1.18 for $\mathrm{Zn}, 0.90$ for Se at site-I and 0.101 for $\mathrm{Co}, 1.38$ for $\mathrm{Ni}, 3.37 \mathrm{for} \mathrm{Cu}$, 174.35 for As, 1.12 for $\mathrm{Zn}$ and 0.95 for Se at site-II. Concerning the consumption routine of residents in sampling area, the daily intake of $\mathrm{As}, \mathrm{Cu}, \mathrm{Ni}$ and $\mathrm{Zn}$ was beyond the oral dose, thus eating of Cucurbita maxima is not considered to be safe for inhabitants of the sampling sites.

Key Words: Heavy metals and metalloids, Cucurbita maxima, Permissible limit, Transfer factor, Pollution load index, Health risk index.

\section{INTRODUCTION}

In Pakistan, industrial wastewater is being used for irrigating 32500 ha land $^{1}$. It is estimated that scarcity of water in agricultural areas will reach up to $33 \%$ of the entire needs in $2025^{2}$. The farmers using municipal wastewater for irrigation can earn more profit (US\$300 approximately) each year as compared to those using fresh water ${ }^{1}$. Wastewater, sometimes allows the farmer to grow crops more than one time in a year. In Pakistan, irrigation of crops with municipal wastewater is a common practice particularly in the peri-urban areas of big cities $^{3}$.

Wastewater enriches the crops with nutrients that are essential for better growth and improved yield. Heavy metals, nitrates, salts and nutrients in sewage water pose a harmful impact on the environment ${ }^{4}$. The continuous utilization of unprocessed water results in the enrichment of soil with both macro and micro-nutrients ${ }^{5,6}$. Wastewater causes a problem in organisms as it contains considerable amount of poisonous heavy metals.

Among various types of pollution, soil pollution with metals may cause severe problems because these metals are firmly attached to soil particles and may persist in soil for a long period. Metals gather in the soil very quickly but removal of metals takes place from soil very slowly either by leaching down in the ground water or by getting into the plant ${ }^{7}$. Soil acts as a natural buffer and reservoir for pollutants, thus it helps control the transfer of ions and chemicals to biota, atmosphere and hydrosphere ${ }^{8}$. For the food production, the soil acts as an essential natural source and plants obtain nutrients from the soil via roots.

The most favorable and low cost way of achieving the essential nutrients for the body is the use of excess fruits and vegetables mainly in those areas where other nutrients are deficient. Vegetables work as a buffer for acidic substances produced during the process of digestion. Due to considerable 
awareness among masses, the vegetable consumption in the last few decades has increased tremendously because of its role in the prevention of certain diseases and presence of key nutritional components essential for human health ${ }^{9}$.

Prolonged intake of foodstuffs containing hazardous metal contents may cause toxicity in humans by disrupting metabolic processes and hence causing a variety of health disorder ${ }^{10}$. For example, high level of $\mathrm{Cu}$ causes toxicity in humans and plants and it disturbs physiological and biochemical processes such as pigment synthesis, photosynthesis, membrane integrity and protein synthesis ${ }^{11-13}$. In severe cases, arsenic toxicity can badly affect the human health, especially hardening of skin, skin pigmentation and lesions and to some extent it can cause neurological disorders and cancer ${ }^{14}$. Symptoms associated with Co toxicity are nausea, vomiting, abdominal pain and respiratory problems such as wheezing and asthma ${ }^{15}$.

Cucurbita maxima (pumpkin), a member of Cucurbitaceae family, is generally cultivated all over the world as a popular vegetable. Aerial parts and fruits of Cucurbita maxima are generally eaten as vegetable. It is an annual or perennial herb and is large and climbing. Its leaves are trifoliate and stem is flexible and succulent ${ }^{16}$. In many countries like India, Brazil, America, Yugoslavia and China, pumpkin is usually used as medicine ${ }^{17}$.

The aim of this study was to assess the levels of $\mathrm{Co}, \mathrm{Ni}$, $\mathrm{Cu}, \mathrm{As}, \mathrm{Zn}$ and Se in Cucurbita maxima and its rhizospheric soil usually irrigated with wastewater in District Sargodha and determined the transfer of metals and metalloids from the soil to the vegetable. We also assessed the pollution load in soil and health risk index due to intake of contaminated Cucurbita maxima from the sampling sites.

\section{EXPERIMENTAL}

This research was conducted in Sargodha District (Central Punjab), Pakistan. Sargodha is present on $32^{\circ} 082003$ north latitude and $73^{\circ} 72003$ east longitude. Sargodha is an agricultural city. The samples of Cucurbita maxima and the rhizospheric soil were taken from peri-urban areas, usually irrigated with municipal wastewater. Two sites were selected for sample collection. Site-I was located at $10 \mathrm{~km}$ radius and site-II at $25 \mathrm{~km}$ radius of Sargodha city. The sampling was done in the month of July and August 2012.

Soil samples: From each site of sampling, the composite soil of almost $1 \mathrm{~kg}$ was collected under the vegetable. The composite soil consisted of 5 sub-samples. To attain randomness, the soil was dug up to $20 \mathrm{~cm}$ depth in a zigzag path. Firstly, the soil samples were dried in air and then dried at $72{ }^{\circ} \mathrm{C}$ in an oven for three consecutive days ${ }^{18}$ and were pulverized and mashed into powder form by using a grinder and sieved. Prior to analysis, the samples were packed into polythene bags.

Vegetable samples: Six replicates of the vegetable (edible part) were collected from each site. Vegetable samples were washed once with distilled water. Edible portions were cut into small pieces with a knife and dried in sunlight and then placed in an oven at $92^{\circ} \mathrm{C}$ for $48 \mathrm{~h}$. Dried samples were ground into powder with the help of an electric grinder.

Digestion of soil samples: $1 \mathrm{~g}$ soil sample was taken in a flask and then added $8 \mathrm{~mL}$ of $\mathrm{H}_{2} \mathrm{O}_{2}$ and $4 \mathrm{~mL}$ of $\mathrm{H}_{2} \mathrm{SO}_{4}$. The samples were placed for $0.5 \mathrm{~h}$ in a digestion chamber at appropriate temperature. After the digestion was completed, $2 \mathrm{~mL}$ of $\mathrm{H}_{2} \mathrm{O}_{2}$ were added to each flask. All samples were heated again until the samples became colourless. After filtering the digests the final volume of each sample was raised to $50 \mathrm{~mL}$ and then stored in plastic bottles until analysis.

Digestion of vegetable samples: $1 \mathrm{~g}$ dried sample of the vegetable was taken in a flask and $4 \mathrm{~mL}$ of $\mathrm{H}_{2} \mathrm{O}_{2}$ and $2 \mathrm{~mL}$ of $\mathrm{H}_{2} \mathrm{SO}_{4}$ were added to it. Further course of the protocol was same as adopted for soil analysis.

Standard preparation and metal analysis: In order to determine accurate values of different metals and metalloids in the soil and vegetable samples, standards of $\mathrm{Co}, \mathrm{Ni}, \mathrm{Cu}, \mathrm{As}$, $\mathrm{Zn}$ and Se were prepared to calibrate the flame photometer and atomic absorption spectrophotometer ${ }^{19}$. All soil and vegetable samples were run on these instruments to determine the concentrations of the six metals in the soil and vegetable.

Quality control: In order to check the level of authentication, repeated comparison was done with the standard reference values (SRM 1570) given by National Institute of Standard and Technology for all metals, mainly in \pm 2 range. To remove any contagion and dependability, the level of quality was checked and at least 5 values were taken by standardizing the instrument. The level of variation was also determined and below 10 was considered authentic.

Statistical analysis: Biostatistics was employed for the data obtained from different analysis using the SPSS software 17. For soil, one-way ANOVA was used and for the vegetable, a two-way ANOVA with interaction was applied on the data. Correlation was also worked out between the soil and the vegetable metal contents. Its significance was tested at $0.001,0.01$ and 0.05 levels of probability ${ }^{20}$.

Transfer factor for vegetable/soil system: To analyze the accumulating capability of metals from the soil to the vegetable, a quantitative assessment of the correlation between the concentration of metal contents in edible portion of vegetable and those in soils was done by the transfer factor (TF) ${ }^{21}$.

$$
\mathrm{TF}=\frac{[\text { Metal }]_{\text {vegetable }}}{[\text { Metal }]_{\text {soil }}}
$$

where: TF stands for transfer factor for vegetable/soil system; [Metal] $]_{\text {vegetable }}$ is the total metal concentration in the edible portion of vegetable, $\mathrm{mg} \mathrm{kg}^{-1}$, in dry matter; [Metal] $]_{\text {soil }}$ is the total metal concentration in soil where this vegetable is grown, $\mathrm{mg} \mathrm{kg}^{-1}$, in dry matter.

Pollution load index: Pollution load index (PLI), for a particular site, has been evaluated ${ }^{22}$.

This parameter is expressed as: $\mathrm{PLI}=$ Metal concentration in investigated soil/reference value of the metal in soil.

Health risk index: The health risk index (HRI) was calculated as the ratio of estimated daily intake of metal via test vegetable and oral reference dose ${ }^{21}$.

$$
\begin{aligned}
& \text { Daily intake of metal (DIM) }=\frac{C_{\text {metal }} \times D_{\text {food intake }}}{B_{\text {Average weight }}} \\
& \text { Health risk index }(H R I)=\frac{D I M}{R_{F} D} 23
\end{aligned}
$$


where: $\mathrm{C}_{\text {metal }}, \mathrm{D}_{\text {food intake }}$ and $\mathrm{B}_{\text {average weight }}$ represent the heavy metal concentrations in vegetable $\left(\mathrm{mg} \mathrm{kg}^{-1}\right)$, daily intake of vegetable $\left(\mathrm{kg} \mathrm{day}^{-1}\right)$ and average body weight $(\mathrm{kg})$, respectively. The average daily vegetable intake rate was calculated by conducting a survey in which 100 people with an average body weight of $60 \mathrm{~kg}$ were asked for their daily consumption of a particular vegetable from the experimental area in each month of sampling ${ }^{23-25}$. Values of $\mathrm{R}_{\mathrm{f}} \mathrm{D}$ for $\mathrm{Co}\left(0.043 \mathrm{mg} \mathrm{kg}^{-1} \mathrm{day}^{-1}\right), \mathrm{Ni}(0.02$ $\mathrm{mg} \mathrm{kg}{ }^{-1}$ day $\left.^{-1}\right), \mathrm{Cu}\left(0.04 \mathrm{mg} \mathrm{kg}^{-1} \mathrm{day}^{-1}\right)$, Se $\left(5 \times 10^{-3} \mathrm{mg} \mathrm{kg}^{-1}\right.$ day $\left.^{-1}\right)$, As $\left(3 \times 10^{-4} \mathrm{mg} \mathrm{kg}^{-1}\right.$ day $\left.^{-1}\right)$ and $\mathrm{Zn}\left(0.3 \mathrm{mg} \mathrm{kg}^{-1}\right.$ day $\left.^{-1}\right)$ were taken from the Integrated Risk Information System ${ }^{26}$. The average daily intake of metals in $0.345 \mathrm{~kg}$ of vegetables per day for adult residents was used ${ }^{24,25}$. An index greater than 1 is considered dangerous to human health ${ }^{23}$.

\section{RESULTS AND DISCUSSION}

Analysis of variance for data in soil showed non-significant $(p>0.05)$ effect of the sites on $\mathrm{Co}, \mathrm{Ni}, \mathrm{Cu}, \mathrm{As}, \mathrm{Zn}$ and $\mathrm{Se}$ concentrations (Table-1). The results of the two-way analysis of variance with interaction in the vegetable and the site showed a significant $(p<0.05)$ effect of the site on Co and $\mathrm{Zn}$ concentrations while the reverse $(p>0.05)$ was true for $\mathrm{Ni}, \mathrm{Cu}$, As and Se concentrations. $\mathrm{Ni}, \mathrm{Cu}, \mathrm{As}, \mathrm{Zn}$ and Se were non-significantly $(p>0.05)$ affected while Co concentration was less significantly $(p<0.05)$ affected by the site and vegetable interaction (Table-2).

\begin{tabular}{cccc} 
TABLE-1 \\
ONE- WAY ANALYSIS OF VARIANCE FOR METALS \\
AND ETALLOIDS IN SOIL AT TWO DIFFERENT \\
SITES IN SARGODHA DISTRICT \\
\hline Metal and metalloid & Site & Metal and metalloid & Site \\
\hline $\mathrm{Co}$ & $0.001^{\text {ns }}$ & $\mathrm{As}$ & $0.000^{\text {ns }}$ \\
$\mathrm{Ni}$ & $0.240^{\text {ns }}$ & $\mathrm{Zn}$ & $0.037^{\text {ns }}$ \\
$\mathrm{Cu}$ & $0.135^{\text {ns }}$ & $\mathrm{Se}$ & $0.015^{\text {ns }}$ \\
\hline ns = not significant. & &
\end{tabular}

\begin{tabular}{cccc}
\multicolumn{4}{c}{ TABLE -2 } \\
\multicolumn{4}{c}{ ANALYSIS OF VARIANCE WITH INTERACTION } \\
\multicolumn{4}{c}{ FOR METALS AND METALLOIDS IN THE } \\
VEGETABLE AT DIFFERENT SITES \\
\hline Metal and metalloid & Site & Vegetable & Site $\times$ vegetable \\
\hline Co & $0.061^{*}$ & $0.225^{* * *}$ & $0.065^{*}$ \\
$\mathrm{Ni}$ & $0.001^{\text {ns }}$ & $0.062^{\text {ns }}$ & $1.421^{\text {ns }}$ \\
$\mathrm{Cu}$ & $1.992^{\text {ns }}$ & $5.807^{\text {ns }}$ & $2.372^{\text {ns }}$ \\
$\mathrm{As}$ & $4.259^{\text {ns }}$ & $104.459^{* * *}$ & $19.010^{\text {ns }}$ \\
Zn & $189.46^{*}$ & $668.163^{* * *}$ & $37.593^{\text {ns }}$ \\
Se & $0.049^{\text {ns }}$ & $0.204^{*}$ & $0.048^{\text {ns }}$ \\
\hline *** = significant at 0.001 level * $=$ & significant at 0.05 level. ns $=$ not \\
significant.
\end{tabular}

Heavy metals and metalloids in soil: At both sites, the levels of metals and metalloids in raw water irrigated soil were found below the maximum permissible limit given by USEPA $^{27,28}$. The concentrations of all heavy metals and metalloids investigated were lower at site-II than those found at site-I of the sampling area except Co and Ni. At site-I, the concentrations of different metals were as Co (19.61), Ni (3.29), $\mathrm{Cu}$ (11.97), As (26.40), Zn (3.84), Se (2.36) and at site-II, Co (19.63), Ni (3.57), Cu (11.76), As (26.39), Zn (3.73), Se (2.29) $\mathrm{mg} \mathrm{kg}^{-1}$, respectively (Table-3).
TABLE-3

CONCENTRATION $\left(\mathrm{mg} \mathrm{kg}^{-1}\right)$ OF SOME METAL AND METALLOID POLLUTANTS IN SOIL SAMPLES OBTAINED FROM TWO DIFFERENT SITES OF DISTRICT SARGODHA

\begin{tabular}{|c|c|c|c|}
\hline \multirow{2}{*}{$\begin{array}{l}\text { Metal and } \\
\text { metalloid }\end{array}$} & \multicolumn{2}{|c|}{ Sampling sites } & \multirow{2}{*}{$\begin{array}{c}\text { Permissible } \\
\text { maximum } \\
\text { limit USEPA }{ }^{27}\end{array}$} \\
\hline & $\begin{array}{c}\text { Site-I } \\
(\text { means } \pm \text { SE) }\end{array}$ & $\begin{array}{c}\text { Site-II } \\
(\text { means } \pm \text { SE) }\end{array}$ & \\
\hline Co & $19.61 \pm 0.174$ & $19.63 \pm 0.320$ & 65 \\
\hline $\mathrm{Ni}$ & $3.294 \pm 0.017$ & $3.577 \pm 0.147$ & 50 \\
\hline $\mathrm{Cu}$ & $11.977 \pm 0.147$ & $11.765 \pm 0.287$ & 50 \\
\hline As & $26.405 \pm 0.290$ & $26.397 \pm 0.256$ & 40 \\
\hline $\mathrm{Zn}$ & $3.848 \pm 0.027$ & $3.737 \pm 0.002$ & 200 \\
\hline $\mathrm{Se}$ & $2.367 \pm 0.031$ & $2.297 \pm 0.017$ & 3 \\
\hline
\end{tabular}

Heavy metals and metalloids in Cucurbita maxima: The total concentrations of heavy metals and metalloids in the vegetable (Cucurbita maxima) collected from the two sub-urban sites of Sargodha city are presented in Table-4.

TABLE-4

CONCENTRATION $\left(\mathrm{mg} \mathrm{kg}^{-1}\right)$ OF SOME METAL AND METALLOID POLLUTANTS IN THE VEGETABLE OBTAINED FROM TWO DIFFERENT SITES OF DISTRICT SARGODHA

\begin{tabular}{|c|c|c|c|}
\hline \multirow{2}{*}{$\begin{array}{l}\text { Metal and } \\
\text { metalloid }\end{array}$} & \multicolumn{2}{|c|}{ Sampling sites } & \multirow{2}{*}{$\begin{array}{l}\text { Permissible } \\
\text { maximum } \\
\text { limit } \mathrm{WHO}^{28}\end{array}$} \\
\hline & $\begin{array}{c}\text { Site-I } \\
(\text { means } \pm \text { SE })\end{array}$ & $\begin{array}{c}\text { Site-II } \\
(\text { means } \pm \text { SE) }\end{array}$ & \\
\hline $\mathrm{Co}$ & $0.554 \pm 0.014$ & $0.760 \pm 0.027$ & 1 \\
\hline $\mathrm{Ni}$ & $4.33 \pm 0.025$ & $4.827 \pm 0.159$ & 2 \\
\hline $\mathrm{Cu}$ & $23.437 \pm 1.326$ & $23.49 \pm 0.261$ & 20 \\
\hline As & $11.72 \pm 0.274$ & $9.097 \pm 0.259$ & 7 \\
\hline $\mathrm{Zn}$ & $61.771 \pm 1.443$ & $58.65 \pm 0.454$ & 50 \\
\hline $\mathrm{Se}$ & $0.835 \pm 0.027$ & $0.833 \pm 0.021$ & - \\
\hline
\end{tabular}

The average concentration of Co in the vegetable tissue (dry wt.) was found to be $0.55 \mathrm{mg} \mathrm{kg}^{-1}$ at site-I and $0.76 \mathrm{mg}$ $\mathrm{kg}^{-1}$ at site-II, respectively. The Co level was lower than the permissible limit of $1 \mathrm{mg} \mathrm{kg}^{-1}$ dry wt. suggested by $\mathrm{WHO}^{29}$. The vegetable Co concentration was, however, higher at siteII than that at site-I.

The concentration of $\mathrm{Ni}$ in the vegetable was $4.82 \mathrm{mg} \mathrm{kg}^{-1}$ at site-II and $4.33 \mathrm{mg} \mathrm{kg}^{-1}$ at site-I, respectively. Higher $\mathrm{Ni}$ concentration was observed at site-I than that observed at siteII. The concentration of $\mathrm{Ni}$ in the vegetable tissue exceeded the permissible limit of $2 \mathrm{mg} \mathrm{kg}^{-1}$ recommended by the $\mathrm{WHO}^{29}$.

The mean vegetable $\mathrm{Cu}$ concentration was recorded to be $23.49 \mathrm{mg} \mathrm{kg}^{-1}$ at site-II and $23.43 \mathrm{mg} \mathrm{kg}^{-1}$ at site-I, respectively. These values at both sites exceeded the permissible limit of $20 \mathrm{mg} \mathrm{kg}^{-1}$ as reported by the $\mathrm{WHO}^{29}$.

The mean vegetable As concentration was $11.72 \mathrm{mg} \mathrm{kg}^{-1}$ at site-I and $9.097 \mathrm{mg} \mathrm{kg}^{-1}$ at site-II, respectively, however, the As concentration reported at site-I was higher than that detected at site-II. The concentration of As in the vegetable tissues at both sampling sites was above the permissible limit of $7 \mathrm{mg}$ $\mathrm{kg}^{-1}$ suggested by the $\mathrm{WHO}^{29}$.

The average $\mathrm{Zn}$ level in the edible parts of Cucurbita maxima was $61.77 \mathrm{mg} \mathrm{kg}^{-1}$ at site-I and $58.65 \mathrm{mg} \mathrm{kg}^{-1}$ at siteII, respectively. The levels of $\mathrm{Zn}$ in the vegetable tissue at both sites exceeded the permissible limit of $50 \mathrm{mg} \mathrm{kg}^{-1}$ as suggested by the $\mathrm{WHO}^{29}$.

The average Se concentration in the edible tissues of the vegetable was $0.835 \mathrm{mg} \mathrm{kg}^{-1}$ at site-I and $0.833 \mathrm{mg} \mathrm{kg}^{-1}$ at 
site-II, respectively, the values at site-I being considerably higher than those at site-II, in this investigation.

The average transfer factor of the selected heavy metals and metalloids at site-I and site-II was calculated as the concentration of metals and metalloids in the vegetable tissues were found to be within the range from $0.028-16.05 \mathrm{mg} \mathrm{kg}^{-1}$. Transfer factor was in order: TF $\mathrm{Zn}(16.05)>\mathrm{TF} \mathrm{Cu}(1.956)>\mathrm{TF}$ $\mathrm{Ni}(1.314)>\mathrm{TF}$ As $(0.443)>\mathrm{TF} \mathrm{Se}(0.350)>\mathrm{TF}$ Co $(0.028)$ at site-I and TF Zn (15.69) > TF Cu (1.996) > TF Ni (1.349) > TF Se (0.362) > TF As (0.344) > TF Co (0.038), at site-II, respectively (Table-5).

TABLE-5

TRANSFER FACTOR (TF) FOR VEGETABLE/SOIL SYSTEM

\begin{tabular}{ccccccc} 
Sampling & \multicolumn{5}{c}{ Transfer factor $\left(\mathrm{mg} \mathrm{kg}^{-1}\right)$} \\
\cline { 2 - 7 } sites & $\mathrm{Co}$ & $\mathrm{Ni}$ & $\mathrm{Cu}$ & $\mathrm{As}$ & $\mathrm{Zn}$ & $\mathrm{Se}$ \\
\hline Site-I & 0.028 & 1.314 & 1.956 & 0.443 & 16.05 & 0.352 \\
Site-II & 0.038 & 1.349 & 1.996 & 0.344 & 15.69 & 0.362 \\
\hline
\end{tabular}

$\mathrm{Ni}(\mathrm{r}=-0.889), \mathrm{Zn}(\mathrm{r}=-0.758)$ and $\mathrm{Se}(\mathrm{r}=-0.797)$ showed negative and significant correlations between soil and vegetable, while $\mathrm{Co}(\mathrm{r}=0.556), \mathrm{Cu}(\mathrm{r}=0.191)$ and $\mathrm{As}(\mathrm{r}=0.203)$ showed positive and non-significant correlations (Table-6).

\begin{tabular}{cccc}
\multicolumn{5}{c}{ TABLE-6 } \\
\multicolumn{4}{c}{ METAL AND METALLOID CORRELATION } \\
BETWEEN SOIL AND VEGETABLE \\
\hline Metal and & Soil-vegetable & Metal and & Soil-vegetable \\
metalloid & $(\mathrm{r})$ & metalloid & $(\mathrm{r})$ \\
\hline $\mathrm{Co}$ & 0.556 & $\mathrm{As}$ & 0.203 \\
$\mathrm{Ni}$ & $-0.889^{* *}$ & $\mathrm{Zn}$ & $-0.758^{* *}$ \\
$\mathrm{Cu}$ & 0.191 & $\mathrm{Se}$ & $-0.797^{* *}$ \\
\hline$* *$ Co
\end{tabular}

$* *$ Correlation is significant at 0.01 level.

Pollution severity and its variation along the sites were determined with the use of pollution load index. The contamination factor at both sites was almost similar. The reference values $^{30}$ of Co, As and Se in soil were 9.1, 29.0 and $0.7 \mathrm{mg} \mathrm{kg}^{-1}$ and for $\mathrm{Ni}, \mathrm{Cu}$ and $\mathrm{Zn}$ were 9.06, 8.39 and $44.19 \mu \mathrm{g} \mathrm{g}^{-1}$ dry matter, respectively ${ }^{31}$. The pollution load index at site-I was in the following sequence: $\mathrm{Se}(3.38)>\mathrm{Co}(2.178)>\mathrm{Cu}(1.427)$ $>\mathrm{As}(0.910)>\mathrm{Ni}(0.363)>\mathrm{Zn}(0.087)$ and at site-II: $\mathrm{Se}(3.281)$ $>\mathrm{Co}(2.181)>\mathrm{Cu}(1.402)>\mathrm{As}(0.91)>\mathrm{Ni}(0.394)>\mathrm{Zn}$ (0.084) (Table-7).

\begin{tabular}{ccccccc}
\multicolumn{7}{c}{ TABLE-7 } \\
\multicolumn{5}{c}{$\begin{array}{c}\text { POLLUTION LOAD INDEX (PLI) FOR } \\
\text { METAL AND METALLOID IN SOIL }\end{array}$} \\
\hline Sampling & \multicolumn{6}{c}{ Pollution load index $\left(\mathrm{mg} \mathrm{kg}^{-1}\right)$} \\
sites & $\mathrm{Co}$ & $\mathrm{Ni}$ & $\mathrm{Cu}$ & $\mathrm{As}$ & $\mathrm{Zn}$ & $\mathrm{Se}$ \\
\hline Site-I & 2.178 & 0.363 & 1.427 & 0.910 & 0.080 & 3.38 \\
Site-II & 2.181 & 0.394 & 1.402 & 0.910 & 0.085 & 3.28 \\
\hline
\end{tabular}

The health risk index due to intake of heavy metals and metalloids via Cucurbita maxima ranged from 0.074-224.63 $\mathrm{mg}$ day $^{-1}$. The risk index at site-I was: As (224.63), $\mathrm{Cu}$ (3.368), $\mathrm{Ni}$ (1.245), Zn (1.183), Se (0.902), Co (0.074) and at site-II: As (174.35), Cu (3.376), Ni (1.387), Zn (1.124), Se (0.957), Co (0.101). Highest risk index was observed due to As and lowest due to Co (Table-8).

It is now widely known that application of a chemical fertilizer to the soil may cause it polluted due to accumulation

\begin{tabular}{ccccccc}
\hline \multicolumn{6}{c}{ TABLE-8 } \\
HEALTH RISK INTAKE (HRI) DUE TO METAL \\
AND METALLOID VIA INTAKE OF VEGETABLE \\
FROM WASTE WATER IRRIGATED SITES \\
\hline $\begin{array}{c}\text { Sampling } \\
\text { sites }\end{array}$ & $\mathrm{Co}$ & $\mathrm{Ni}$ & $\mathrm{Cu}$ & $\mathrm{As}$ & $\mathrm{Zn}$ & $\mathrm{Se}$ \\
\hline Site-I & 0.074 & 1.244 & 3.368 & 224.63 & 1.183 & 0.902 \\
Site-II & 0.101 & 1.387 & 3.376 & 174.35 & 1.124 & 0.957 \\
\hline
\end{tabular}

of a variety of toxic metals. In the present study, high amount of arsenic, while low of $\mathrm{Ni}$ was found. The concentrations of all heavy metals in the soils of both sites were below the maximum permissible limit. The use of wastewater for irrigation changes the chemical and physical properties of soil and uptake of metal by vegetables ${ }^{32}$. Uncontrolled accumulation of metals and metalloids in soil is detrimental because these are extremely toxic and once accumulated in soil, they cannot be easily eliminated. Soil $\mathrm{Zn}, \mathrm{Ni}$ and $\mathrm{Cu}$ levels found in the present investigation were similar to those found at some different sites in the Faisalabad region ${ }^{33}$.

Among all the heavy metals and metalloids, Zn concentration was the maximum and Co the minimum in the vegetable at both sites. The levels of all metals and metalloids were above the maximum permissible limit except those of Co. The heavy metal concentrations in vegetables are believed to vary from site to site and differ from one vegetable species to the other. This may be due to translocation of metals in different parts of plants or uptake capacity of a vegetable through its $\operatorname{roots}^{34,35}$. It can also be due to the different characteristics of soil such as organic contents, acidity and ability of plant roots to penetrate where the toxic metals are present. Metal concentration differs among vegetables as it depends on absorption capacity of metals and physico-chemical characteristics and nature of soil, which are changed by anthropogenic and environmental interferences and type of plant ${ }^{35}$. Radwan and Salama $^{36}$, also found highest concentration of $\mathrm{Zn}$ in some vegetables collected from Egyptian markets. Due to variations in absorption of metals in plants through roots and their further translocation within the plant parts, edible parts of vegetables showed variations in heavy metal concentrations ${ }^{34}$. Contrary to these findings, Khimpa et al. ${ }^{37}$ determined lower levels of $\mathrm{Zn}$ and $\mathrm{Cu}$ in some vegetables grown in the vicinity of closed dumpsite, Tanzania. The $\mathrm{Cu}, \mathrm{Ni}$ and $\mathrm{Zn}$ levels in pumpkin in the present investigation were similar to those observed by Hussain et al. $^{33}$ at some sites of Faisalabad, Pakistan.

Among the selected metals, $\mathrm{Zn}$ showed maximum values of transfer factor, which ranged from 15.69-16.05 at both sites and it was minimum for Co, ranging from 0.028-0.038. Transfer factors for $\mathrm{Cu}, \mathrm{Zn}$ and $\mathrm{Ni}$ were greater than 1 while for $\mathrm{Co}$, As and Mo were lower than 1 (Table-3). Transfer factor varies from vegetable to vegetable due to differences in uptake of elements and metal concentration in $\operatorname{soil}^{38}$. The high transfer values for $\mathrm{Zn}, \mathrm{Cu}$ and $\mathrm{Ni}$ from soil to plant indicate a strong accumulation of the respective metals by the vegetable. The transfer factors for $\mathrm{Zn}, \mathrm{Ni}$ and $\mathrm{Cu}$ in the present findings were similar to the earlier study conducted by Ullah et al. ${ }^{3}$ while the transfer factors of $\mathrm{Zn}, \mathrm{Cu}$ and $\mathrm{Ni}$ from the soil to the vegetable were higher in the present study than the values reported by Chao et al. ${ }^{39}$. 
Pearson correlation coefficient was calculated to ascertain the relationship of metal between variables ${ }^{40}$. The highest correlation was found for Co while the correlation due to $\mathrm{Ni}$ between soil and vegetable was lower. Correlation between soil and plant depends on the availability of metals in soil. Zn, $\mathrm{Ni}$ and Se showed negative and significant correlations. The negative sign indicates that there is a weak correlation between the soil and the vegetable. These results showed the mineral imbalance of these metals among soil and vegetable. $\mathrm{Co}, \mathrm{Cu}$ and As reveal positive and non-significant correlations indicating a strong association between the soil and the vegetable.

The suitability of soils for agricultural use can be further assessed by using pollution load index which assesses the environmental risk caused by contaminated soils. In the present study, the pollution load indices observed for $\mathrm{Co}, \mathrm{Cu}$ and $\mathrm{Se}$ were greater than 1 , which can cause environmental hazardous effects while for $\mathrm{Ni}$, As and $\mathrm{Zn}$ were lower than 1, which do not pose environmental risk. Highest pollution load index was observed due to Se while that due to $\mathrm{Zn}$ was lowest at both sites. The pollution load due to investigated metals and metalloids was similar at both sites. The pollution load index due to As was higher in the present investigation, whereas that of $\mathrm{Zn}$ was lower than the findings of Oti-Wilberforce and Nwabue ${ }^{41}$. The results of the current investigation indicate that the sampling area is facing hazardous toxicity due to $\mathrm{Co}, \mathrm{Cu}$ and $\mathrm{Se}$, while no toxic effects due to soil $\mathrm{Ni}, \mathrm{As}$ and $\mathrm{Zn}$ concentrations could be assessed.

The metal accumulation in edible portions of different vegetables may have a direct impact on inhabitant's health, consuming such vegetables. At both sites, the population was at a greater risk of $\mathrm{As}, \mathrm{Zn}, \mathrm{Cu}$ and $\mathrm{Ni}$ since their values were greater than 1 while the values observed for $\mathrm{Co}$ and Se were lower than 1 at both sites. The human population will have no risk, if the ratio is lower than 1 , but if the ratio is equal or greater than 1 , the population may experience health risk ${ }^{42}$. The health risk assessment is dependent on physical characteristics of soil, its chemical composition, vegetable type and rate of consumption of vegetables ${ }^{43}$. To avoid the toxic metal accumulation in food chain, standard monitoring of metal contents in vegetables is necessary in contaminated areas. Health risk indices due to $\mathrm{Cu}, \mathrm{Ni}$ and $\mathrm{Zn}$ were higher in the present study than those recorded by Singh et al. ${ }^{31}$ in pumpkin irrigated with wastewater in India. Health risk index observed in this research due to $\mathrm{Cu}$ and $\mathrm{Zn}$ was higher than those reported by Cui et $a l .^{21}$. The findings of our study indicate that there is a potential hazard of toxicity in humans due to As, Zn, $\mathrm{Cu}$ and $\mathrm{Ni}$ in the sampling areas.

\section{REFERENCES}

1. J.H.J. Ensink, T. Mahmood, W. Vander-Hoek, L. Raschid-Sally and F.P. Amera-Singhe, Water Policy, 6, 1 (2004).

2. Anonymous, Key Issue of Concern Part-3, State of Environmental Report. Ministry of Environment, Pakistan (2005).

3. H. Ullah, I. Khan and I. Ullah, Environ. Monit. Assess., 184, 6411 (2012).

4. F. Stagnitti, J. Sherwood, G. Allinson, L. Evans, M. Allinson, L. Li and I. Phillips, J. Agric. Res., 41, 603 (1998).

5. D. Dass and R.N. Kaul, Greening Wasteland through Wastewater. National Wastelands Development Board, Ministry of Environment and Forest, New Delhi, India, p. 33 (1992).
6. V. Kanan, R. Ramesh and C. Sasikumar, J. Environ. Biol., 26, 269 (2005).

7. B.J. Alloway, Heavy Metals in Soils, John Wiley \& Sons, Glasgow, pp. 122-151 (1990).

8. R. Miroslav and N.B. Vladimir, Prac.. Environ. Anal. Royal Soc. Chem., 2, 263 (1999)

9. S.H. Badaway, M.I.D. Helal, A.M. Chaudri, K. Lawlor and S.P. McGrath, Environ. Int. J., 5, 535 (2000).

10. L. Jarup, Br. Med. Bull., 68, 167 (2003).

11. H. Marschnar, Mineral Nutrition of Higher Plants, Academic Press: London, edn 2, pp. 33-347 (1995).

12. W.P. Miller, W.W. McFee and A.M. Alston, J. Environ. Qual., 12, 29 (1983).

13. R.H. Merry, K.G. Tiller and A.M. Alston, Plant Soil, 91, 115 (1989).

14. P. Ravenscroft, H. Brammer and K. Richards, Arsenic Pollution: A Global Synthesis (2009).

15. ATSDR, Department of health and human services, Public Health Service Agency for Toxic Substances and Disease Registry (2004).

16. K.R. Kirtikar and B.D. Basu, Indian Medicinal Plants, Oriental Enterprises. India, edn. 2, pp. 1606-1608 (2003).

17. M. Popovic, Savremena Poljoprivreda, 11, 59 (1971).

18. C.D. Campbell and C.O. Planks, Regul. Toxicol. Pharmacol., 16, 265 (1992).

19. W.L. Lindsay and W.A. Norvell, Soil Sci. Soc., 42, 421 (1978)

20. R.G.D. Steel and J.H. Torrie, Principles and Procedures of Statistics. A Biometrical Approach, New York: McGraw Hill Book Co, edn. 2 (1980).

21. Y.J. Cui, Y.G. Zhu, R.H. Zhai, D.Y. Chen, Y.Z. Huang, Y. Qui and J.Z. Liang, Environ. Int., 30, 785 (2004).

22. W. Liu, J.Z. Zhao, Z.Y. Ouyang, L. Söderlund and G.H. Liu, Environ. Int., 31, 805 (2005).

23. USEPA (US Environmental Protection Agency), Region 9, Preliminary Remediation Goals (2002).

24. K.Y. Ge, The Status of Nutrient and Meal of Chinese in the 1990s. Beijing People's

25. Hygiene Press, pp. 415-434 (1992).

26. X. Wang, T. Sato, B. Xing and S. Tao, Sci. Total Environ., 350, 28 (2005).

27. US Environmental Protection Agency, Integrated Risk Information System (2010).

28. USEPA, US Environmental Protection Agency, Exposure Factors Handbook. Volume II-Food Ingestion Factors (1997).

29. WHO, Trace Elements in Human Nutrition and Health, World Health Organization, Geneva (1996).

30. Dutch Standards, Circular on Target Values and Intervention Values for soil remediation (2000).

31. A. Singh, R.K.M. Sharma, M. Agarwal and F.M. Marshall, Food Chem. Toxicol., 48, 611 (2010).

32. M. Arora, B. Kiran, S. Rani, A. Rani, B. Kaur and N. Mittal, Food Chem., 111, 811 (2008).

33. S.I. Hussain, A. Ghafoor, S. Ahmad, G. Murtaza and M. Sabir, Pak. J. Agric. Sci., 43, 3 (2006).

34. D. Vousta, A. Grimanis and C. Samara, Environ. Pollut., 94, 325 (1996).

35. G. Zurera, B. Estrada, F. Rincon and R. Pozo, Bull. Environ. Contam. Toxicol., 38, 805 (1987).

36. M.A. Radwan and A.K. Salama, Food Chem. Toxico., 44, 1273 (2006).

37. C. Kihampa, W.J.S. Mwegoha and R.S. Shemdoe, Int. J. Environ. Sci., 2, 889 (2011).

38. P. Zhuang, B.M. Murray, X. Hanping, N. Li and Z. Li, Sci. Total Environ., 407, 1551 (2009).

39. W. Chao, L.X. Chen, Z.L. Mini, W.P. Fang and G.Z. Yong, Polish J. Environ. Stud., 16, 2 (2007).

40. A. Pentecost, Analyzing Environmental Data. In testing if a Relationship Occurs Between Two Variables using Correlation, Pearson Education Limited, England, pp. 102-106 (1999).

41. J.O. Oti-Wilberforce and F.I. Nwabue, Environ. Pollut., 2, 1 (2013).

42. K. Sajjad, R. Farooq, S. Shahbaz, M.A. Khan and M. Sadique, World App. Sci. J., 6, 1602 (2009).

43. G.P. Cobb, K. Sands, M. Waters, B.G. Wixson and E. Dorward-King, Environ. Toxicol. Chem., 19, 600 (2000). 